\title{
Эллипсометрия субмиллиметрового диапазона в задачах диагностики композиционных материалов
}

\author{
В.Н. Федоринин ${ }^{1}$, С.А. Кузнецов ${ }^{1,2}$, А.В. Гельфанд ${ }^{1}$, А.Ю. Горшков ${ }^{1}$ \\ ${ }^{1}$ Новосибирский филиал Института физики полупроводников им. А.В. Ржанова СО РАН "КТИПМ", \\ Новосибирск, 630090, пр. Академика Лаврентьева, 2/1 \\ ${ }^{2}$ Новосибирский государственный университет, Новосибирск, 630090, Пирогова, 2
}

DOI 10.34077/RCSP2021-50

Создание новых материалов и способов конструирования является важным направлением научнотехнологического развития в РФ. Одно из составляющих данного направления состоит в развитии технологии композиционных материалов, обладающих высокими механическими, технологическими и эксплуатационными свойствами.

При создании, воспроизводстве и эксплуатации композитных материалов к неотъемлемым задачам относятся контроль и прогнозирование механизмов формирования структуры и фазообразования связующих компонент на границах раздела и в межволоконном пространстве, выявление зарождающих и накопленных дефектов, а также деградации материала в процессе его эксплуатации.

В настоящей работе рассматривается техника эллипсометрии с использованием субмиллиметровых волн для диагностики оптически непрозрачных композиционных материалов. Объемная структура композиционного материала рассматривается как гетерогенная среда, которая характеризуется комплексной диэлектрической функцией. В рамках однослойной физической модели рассматривается возможность регистрации расслоения в многослойной пленочной структуре композиционного материала, изготовленного на основе препрег Тоrayca Т800.

Представлен экспериментальный образец эллипсометра, выполненного по нулевой схеме и работающего на частоте 139 ГГц (Рис.1а) В эллипсометре применены уникальные поляризационные оптические элементы, включающие поляризатор, анализатор, четвертьволновые пластинки, которые реализованы на основе самокомплементарных метаповерхностей с подстилающем несущим слоем диэлектрика толщиной 20 мкм.

Представлены результаты эллипсометрических измерений тестовых объектов, изготовленных в СибНИА им. С.А. Чаплыгина. Показана возможность обнаружения фактора расслоения структуры композиционного материала на основе углеродных волокон в глубине 0.5 мм.

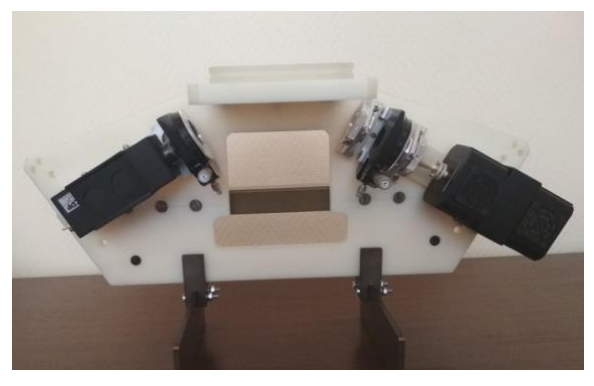

a)

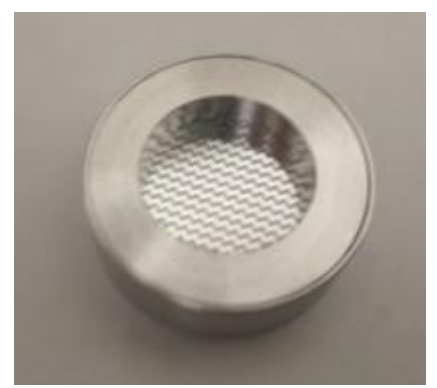

б)

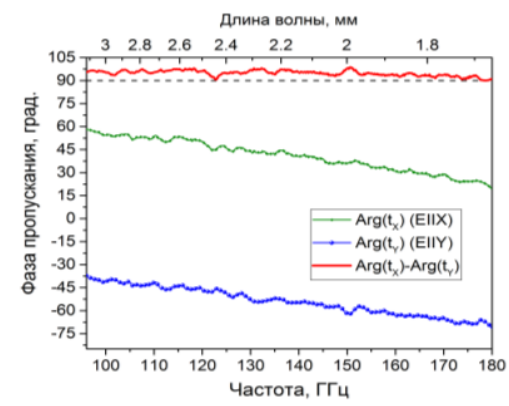

B)

Рис.1 Фотографии экспериментального образца субмиллиметрового эллипсометра (а), четвевертьволновой пластинки (б) и фазовые спектры последней (в). 